\title{
Zinc and copper as feed additives, growth factors or unwanted environmental factors
}

\author{
Hanne D. Poulsen \\ Department for Animal Nutrition and Physiology, \\ Danish Institute of Agricultural Sciences, Research Centre Foulum \\ P.O. Box 50, DK-8830 Tjele, Denmark
}

\section{ABSTRACT}

Zinc $(\mathrm{Zn})$ and copper $(\mathrm{Cu})$ are essential nutrients. However, the functions and interplay between these two minerals remain to be fully understood, especially in the feeding of piglets, where $\mathrm{Cu}$ is used as a "growth promoter". The process of weaning imposes a lot of changes in the dietary conditions which may contribute to the weaning problems. Besides being heavy metals, $\mathrm{Cu}$ and $\mathrm{Zn}$ are required in the functioning of the young pig. Thus, further studies of the basic functions and interplay between $\mathrm{Cu}$ and $\mathrm{Zn}$ in relation to environmental aspects are needed.

KEY WORDS: zinc, copper, young pigs, feed additives, nutrition, environment

\section{INTRODUCTION}

Zinc $(\mathrm{Zn})$ and copper $(\mathrm{Cu})$ have structural or catalytic roles in many metalloproteins that function as enzymes. $\mathrm{Zn}$ in particular participates in several enzymes which are of great importance for growth and development. $\mathrm{Zn}$ is deeply involved in the metabolism of DNA and protein, and as such is very important in cell differentiation and cell replication. As a result, the $\mathrm{Zn}$ requirement is greatest in fastgrowing animals, and the effects of $\mathrm{Zn}$ deficiency are most harmful in foetuses and young animals, where cell differentiation and replication are highest (Apgar, 1985; 
Keen and Hurley, 1987). Furthermore, $\mathrm{Zn}$ is important for the functioning of the immune system (Keen and Gerschwin, 1990). Cu is substantially involved in processes concerning iron utilisation and synthesis of connective tissue (Prohaska, 1988). Consequently, $\mathrm{Zn}$ and $\mathrm{Cu}$ are essential nutrients and both are classified within the group of trace minerals.

\section{COPPER AS A GROWTH FACTOR}

Since the inclusion of large amounts of $\mathrm{Cu}$ results in an increase in daily gain and feed conversion ratio, $\mathrm{Cu}$ has been used as a "growth promoter" in pig production for several decades. However, the mechanisms behind the growth stimulating effect remain a matter of controversy. It has long been hypothesised that $\mathrm{Cu}$ exerts a growth-limiting effect on the intestinal microflora, thus leaving more nutrients available for absorption to the pig. However, Fuller et al. (1960), reported no apparent differences between the microflora in $\mathrm{Cu}$ supplemented and non-supplemented pigs. In contrast, Kirchgessner et al. (1976) found that addition of dietary $\mathrm{Cu}$ increased protein utilisation, probably through activation of pepsin. Later it was hypothesised that $\mathrm{Cu}$ supplementation exerts an effect on the villus structure and thus decreases the turnover of the intestinal cells, possibly through an interaction (Shurson et al., 1990; Radecki et al., 1992). This would likewise result in more nutrients becoming available for absorption.

Recently, it has been claimed that the growth promoting effect is a systemic effect within the body rather than an antimicrobial effect in the intestinal tract (Zhou et al., $1994 \mathrm{a}, \mathrm{b})$. Although the growth-promoting effect is not valid under all conditions, the greatest effect of $\mathrm{Cu}$ addition is generally recorded in young pigs. Thus $\mathrm{Cu}$ addition has been restricted to feeds for young pigs from weaning (Table 1).

TABLE 1

Recommended and allowed dietary levels of copper $(\mathrm{Cu})$ and zinc $(\mathrm{Zn})$ in Denmark

\begin{tabular}{lccccc}
\hline & \multicolumn{2}{c}{ Recommended } & & \multicolumn{2}{c}{ Allowed $^{1}$} \\
\cline { 2 - 3 } \cline { 5 - 6 } & $\mathrm{Cu}$ & $\mathrm{Zn}$ & & $\mathrm{Cu}$ & $\mathrm{Zn}$ \\
\hline mg/kg diet: & 6 & & & $175^{2}$ & 250 \\
piglets & 6 & 100 & & 35 & 250 \\
growing-finishing pigs & 6 & 100 & & 35 & 250 \\
sows & 6 & 100 & & \\
\hline
\end{tabular}

${ }^{1}$ total dietary content

${ }^{2}$ until 17 weeks of age 


\section{ZINC AS A GROWTH FACTOR}

Inclusion of high amounts of $\mathrm{Zn}$ (about $2.500 \mathrm{ppm} \mathrm{Zn}$ as zinc oxide) in diets fed to piglets for two weeks after weaning has an inhibitory effect on the incidence and severity of unspecific post-weaning scouring and/or daily gain (Poulsen, 1989, 1995; Hahn and Baker, 1993). The functional evidence behind this beneficial effect remains to be demonstrated, but the above-mentioned effects on growth and diarrhoea were coincident with an increase in $\mathrm{Zn}$ concentration in plasma. A decrease in plasma $\mathrm{Zn}$ is seen in connection with $E$. coli infections in chickens (Butler and Curtin, 1973) and in pigs challenged with endoxin (Chesters and Will, 1981). Furthermore, $\mathrm{Zn}$ retention is reduced in young pigs with intestinal infections (Whitenack et al., 1978). These findings suggest that piglets fed too little dietary $\mathrm{Zn}$ may be more susceptible to infections. In addition, it should be noted that negative $\mathrm{Zn}$ balance is seen in humans with intestinal infections, probably caused by massive secretory loss into the intestine (Prasad, 1985). Usually, endogenous $\mathrm{Zn}$ is secreted via the pancreatic juice (Sternlicb, 1988). However, compared with the daily intake of $\mathrm{Zn}$, the secretion of $\mathrm{Zn}$ in pancreatic juice is low (Jensen et al., 1998). $\mathrm{Zn}$ is also secreted into the intestinal lumen from the intestinal cells and is also lost with discharged intestinal cells (Cousins, 1985). The urinary excretion of $\mathrm{Zn}$ is normally very low (Poulsen and Larsen, 1995). The labile $\mathrm{Zn}$ pool in the pig body is small (Larvor, 1983), and thus a constant dietary supply is necessary. In humans, Zn deficiency can cause non-thriving and diarrhoea (Golden and Golden, 1985). Frequently, cases of human non-specific diarrhoea are improved with $\mathrm{Zn}$ therapy (McClain et al., 1988). In pigs, failure to thrive is one of the first symptoms of $\mathrm{Zn}$ deficiency, yet diarrhoea is also recorded (Brink et al., 1959). These reports emphasise that $\mathrm{Zn}$ is indeed an essential nutrient, and demonstrate the importance of a sufficient dietary supply of $\mathrm{Zn}$ to young pigs. But more specific knowledge is still required.

Until now, little attention has been ascribed to define the absolute digestibility (availability) of $\mathrm{Zn}$ in the different inorganic and organic sources used for dietary supplementation. However, the apparent digestibility of $\mathrm{Zn}$ in zinc oxide has been shown to be as low as $20 \%$ (Poulsen and Larsen, 1995). Furthermore, studies have revealed differences in the relative availability when different sources are compared with a standard source (Wedekind and Baker, 1990; Wedekind et al., 1992).

\section{INTERACTIONS BETWEEN Zn AND Cu}

Interactions between $\mathrm{Zn}$ and $\mathrm{Cu}$ have been demonstrated. In the intestinal tract, the metabolism of the two trace elements is closely coupled to thionein (Cousins, 1985). $\mathrm{Zn}$ and maybe also $\mathrm{Cu}$ can induce the synthesis of this protein in the intes- 
tinal cells. As a result, thionein binds $\mathrm{Zn}$ and $\mathrm{Cu}$ by forming metallothionein. Apparently, $\mathrm{Zn}$ is superior in inducing the synthesis of thionein, whereas the affinity of thionein is greater for $\mathrm{Cu}$ than for $\mathrm{Zn}$ (Cousins, 1985). $\mathrm{Zn}$ seems to play the more active and $\mathrm{Cu}$ the more passive role (Davis and Mertz, 1987). From the intestinal cells, $\mathrm{Zn}$ and $\mathrm{Cu}$ may be transferred to the portal vein, or $\mathrm{Zn}$ and $\mathrm{Cu}$ may be secreted into the intestinal lumen or lost by discharge of the intestinal cells.

When $\mathrm{Cu}$ is added to pig diets at growth promoting levels, the interactions between $\mathrm{Zn}$ and $\mathrm{Cu}$ may cause problems, i.e. it can result in $\mathrm{Zn}$ deficiency, which needs to be rectified by $\mathrm{Zn}$ supplementation. Furthermore, the dietary $\mathrm{Cu}$ level seems to affect the outcome of inclusion of high amounts of $\mathrm{Zn}$ (as zinc oxide) in the diets for nowly weaned piglets (Poulsen, 1995). By the above-mentioned intestinal antagonistic interaction, high dietary inclusion of $\mathrm{Zn}$ may also result in $\mathrm{Cu}$ deficiency (Davis and Mertz, 1987). However, these aspects need further clarification.

\section{EXCLUSIVELY ESSENTIAL GROWTH FACTORS ?}

As already mentioned, there is still controversy in the defining and understanding of the function of $\mathrm{Cu}$ when it is used as a "growth promoter". In addition, recent studies have revealed positive effects following the inclusion of $\mathrm{Zn}$ (as zinc oxide) in diets for newly weaned piglets. Therefore, heavy $\mathrm{Cu}$ and/or $\mathrm{Zn}$ supplementation of pig diets is clearly still a matter of complexity and of concern. Firstly, it may cause problems with interactions, especially the antagonistic interactions, which will often require readjustments of the dietary need for the interacting mincral(s). Secondly, chronic poisoning has been reported in sheep grazing herbage dressed with liquid manure from pigs fed $\mathrm{Cu}$-supplemented diets (Davis and Mertz, 1987); therefore such pig manure is potentially toxic to sheep. Thirdly, the heavy inclusion of $\mathrm{Cu}$ and/or $\mathrm{Zn}$ may pose environmental problems, because the dietary $\mathrm{Cu}$ and/or $\mathrm{Zn}$ will be concentrated in the pig wastes and later spread on the arable land. This may result in substantial increases in the soil content of these minerals.

Calculations have been made, based on the maximum allowed pig density in Denmark and on standard values of feed intake, dietary mineral content and mineral retention, of the amounts of $\mathrm{Cu}$ spread per hectar (ha) of arable land, for different scenarios (Table 2). Furthermore, it was calculated how many years of manure application will pass until the upper soil quality criteria is reached in a standard soil (Larsen et al., 1996). The critical value for soil $\mathrm{Cu}$ content is laid down by the Danish Environmental Protection Agency for sludge and is based on the EU Directive 86/278/EØF (Larsen et al., 1996). It is assumed in the calculations that the $\mathrm{Cu}$ contribution per ha originates exclusively from pig manure, and that 
TABLE 2

Calculated copper $(\mathrm{Cu})$ content and accumulation in the soil at different hypothetical cases

\begin{tabular}{|c|c|c|c|c|}
\hline & $\mathrm{A}^{\prime}$ & $\mathrm{B}^{\prime}$ & $\mathrm{C}^{\prime}$ & $\mathrm{D}^{1}$ \\
\hline \multicolumn{5}{|l|}{ Growing- finishing pigs, $30-100 \mathrm{~kg}$ : } \\
\hline dietary intake, $\mathrm{g} / \mathrm{pig}$ & 2.0 & 14.4 & 17.3 & 33.6 \\
\hline retained in the body, g/pig & 0.1 & 0.1 & 0.1 & 0.1 \\
\hline excreted by urine and faeces, g/pig & 1.9 & 14.3 & 17.2 & 33.5 \\
\hline $\mathrm{g} \mathrm{Cu} / 5 \mathrm{l} \mathrm{pigs} / \mathrm{ha} /$ year & 100 & 730 & 875 & 1700 \\
\hline removal with crop, $\mathrm{g} / \mathrm{ha} /$ year $^{2}$ & 30 & 30 & 30 & 30 \\
\hline accumulation, $\mathrm{g} / \mathrm{ha} /$ year & 70 & 700 & 845 & 1670 \\
\hline number of years to reach $40 \mathrm{mg} \mathrm{Cu} / \mathrm{kg}$ soil $^{3}$ & 1300 & 130 & 110 & 50 \\
\hline \multicolumn{5}{|l|}{ Year sow incl. 22 piglets, to $30 \mathrm{~kg}$ : } \\
\hline dietary intake, g/unit & 22.9 & 193.6 & 80.5 & \\
\hline retained in the body, $g /$ unit & 1.4 & 1.4 & 1.4 & \\
\hline excreted by urine and faeces, $g /$ unit & 21.5 & 192.2 & 79.1 & \\
\hline $\mathrm{g} \mathrm{Cu} / 4.5$ year sow, incl .22 piglets & 100 & 865 & 355 & \\
\hline removal with crop, $\mathrm{g} / \mathrm{ha} / \mathrm{year}^{2}$ & 30 & 30 & 30 & \\
\hline accumulation, $\mathrm{g} /$ ha/year & 70 & 835 & 325 & \\
\hline number of years to reach $40 \mathrm{mg}$. Cu/kg soil ${ }^{3}$ & 1300 & 110 & 280 & \\
\hline
\end{tabular}

$1 \mathrm{~A}: 10 \mathrm{mg} \mathrm{Cu} / \mathrm{kg}$ (normal content in feed without $\mathrm{Cu}$ addition) for all categories

$\mathrm{B}$ : at maximum allowed $\mathrm{Cu}$ addition for all categories

$\mathrm{C}$ : if $90 \mathrm{mg} \mathrm{Cu} / \mathrm{kg}$ for piglets, $90 \mathrm{mg} \mathrm{Cu} / \mathrm{kg}$ for slaughter pigs during the entire period, and $10 \mathrm{mg}$ $\mathrm{Cu} / \mathrm{kg}$ for sows

$\mathrm{D}$ : if $175 \mathrm{mg} \mathrm{Cu} / \mathrm{kg}$ for slaughter pigs during the entire growth period

2 wheat

${ }^{3}$ calculated on the basis of a $20 \mathrm{~cm}$ deep ploughing and a specific gravity of 1.5 , i.e. in case of an addition of $3 \mathrm{~kg} \mathrm{Cu} / \mathrm{ha}$, the $\mathrm{Cu}$ content will increase by $1 \mathrm{mg} / \mathrm{kg}$ (dry soil). The natural soil content is estimated at $10 \mathrm{mg} / \mathrm{kg}$ (Magid,1997)

the amount taken away by a standard crop (wheat) approximates $30 \mathrm{~g}$ per ha. Table 2 shows that when $\mathrm{Cu}$ is used as a "growth promoter" at allowed Danish (and EU) levels, it will only take about 110 years, before the $\mathrm{Cu}$ content in the soil reaches the given critical value. When $\mathrm{Cu}$ supplementation is used from weaning until slaughter, which is not allowed in Denmark (or in the EU), the critical value will be reached within 50 years. In evaluating the risk of heavy metal accumulation and pollution of the soil, it is important to be aware of the fact that it takes much longer to get rid of the accumulated amounts than it takes to reach the critical values.

Some values on the corresponding $\mathrm{Zn}$ accumulation in some hypothetical cases are shown in Table 3. It is obvious that the $\mathrm{Zn}$ situation is not as critical as the $\mathrm{Cu}$ case. However, $\mathrm{Zn}$ accumulation may become a problem, especially in cases where the maximum allowed dietary $\mathrm{Zn}$ content is used in practice. 
TABLE 3

Calculated zinc $(\mathrm{Zn})$ content and accumulation in the soil at different hypothetical cases

\begin{tabular}{|c|c|c|c|c|}
\hline & $\mathrm{A}^{\prime}$ & $\mathrm{B}^{1}$ & $\mathrm{C}^{\prime}$ & $\mathrm{D}^{\prime}$ \\
\hline \multicolumn{5}{|l|}{ Growing - finishing pigs, $30-100 \mathrm{~kg}$ : } \\
\hline dietary intake, g/pig & 19.2 & 48.1 & & \\
\hline retained in the body, g/pig & 1.4 & 1.4 & & \\
\hline excreted by urine and faeces, g/pig & 17.8 & 46.7 & & \\
\hline $\mathrm{g} \mathrm{Zn} / 51 \mathrm{pigs} / \mathrm{ha} /$ year & 910 & 2380 & & \\
\hline removal with crop, g/ha/year ${ }^{2}$ & 200 & 200 & & \\
\hline accumulation, $\mathrm{g} / \mathrm{ha} /$ year & 710 & 2180 & & \\
\hline number of years to reach $1000 \mathrm{mg} \mathrm{Zn} / \mathrm{kg}$ soil $^{3}$ & 380 & 125 & & \\
\hline \multicolumn{5}{|l|}{ Year sow incl. 22 piglets, to $30 \mathrm{~kg}$ : } \\
\hline dietary intake, g/unit & 208.4 & 522.2 & 736.4 & 1017 \\
\hline retained in the body, g/unit & 14.4 & 14.4 & 14.4 & 14.4 \\
\hline excreted by urine and faeces, g/unit & 194.0 & 507.8 & 722 & 1002.8 \\
\hline g Zn/4.5 year sow (incl. 22 piglets) & 875 & 2290 & 3250 & 4510 \\
\hline removal with crop, $\mathrm{g} / \mathrm{ha} / \mathrm{year}^{2}$ & 200 & 200 & 200 & 200 \\
\hline accumulation, $\mathrm{g} / \mathrm{ha} /$ year & 675 & 2090 & 3050 & 4310 \\
\hline number of years to reach $100 \mathrm{mg} \mathrm{Zn} / \mathrm{kg}$ soil ${ }^{3}$ & 340 & 110 & 75 & 55 \\
\hline \multicolumn{5}{|c|}{${ }^{1} \mathrm{~A}: 100 \mathrm{mg} \mathrm{zn} / \mathrm{kg}$ (normal recommended content) for all categories } \\
\hline \multicolumn{5}{|c|}{$\mathrm{B}$ : at maximum allowed $\mathrm{Zn}$ addition for all categories } \\
\hline \multicolumn{5}{|c|}{$\begin{array}{l}\mathrm{C} \text { : if } 2500 \mathrm{mg} \mathrm{Zn} / \mathrm{kg} \text { for piglets for two weeks after weaning and then } 100 \mathrm{mg} / \mathrm{kg} \text { and } \mathrm{mg} \mathrm{Zn} / \mathrm{kg} \\
\text { for sows }\end{array}$} \\
\hline \multirow{2}{*}{\multicolumn{5}{|c|}{$\begin{array}{l}\text { D: if } 2500 \mathrm{mg} \mathrm{Zn} / \mathrm{kg} \text { for piglets for two weeks after weaning and then } 250 \mathrm{mg} / \mathrm{kg} \text {, and } 250 \mathrm{mg} \\
\mathrm{Zn} / \mathrm{kg} \text { for sows }\end{array}$}} \\
\hline & & & & \\
\hline \multicolumn{5}{|l|}{2 wheat } \\
\hline \multicolumn{5}{|c|}{$\begin{array}{l}{ }^{3} \text { calculated on the basis of a } 20 \mathrm{~cm} \text { deep ploughing and a specific gravity of } 1.5 \text {, i.e. in case of an } \\
\text { addition of } 3 \mathrm{~kg} \mathrm{Zn} / \mathrm{ha} \text {, the } \mathrm{Zn} \text { content will increase by } 1 \mathrm{mg} / \mathrm{kg} \text { (dry soil). The natural soil content } \\
\text { is estimated at } 25 \mathrm{mg} / \mathrm{kg} \text { (Magid, 1997) }\end{array}$} \\
\hline
\end{tabular}

\section{CONCLUSIONS}

Summing up, $\mathrm{Zn}$ and $\mathrm{Cu}$ are essential nutrients, and also nutrients that play a special and very important role in young, newly-weaned piglets. However, the specific functions and interplay between the two minerals remain to be fully understood. The process of early weaning imposes a lot of changes in the dietary and the housing conditions. These changes contribute to the problems frequently seen after weaning (diarrhoea, reduced growth etc.). Evidently, the supply of both $\mathrm{Zn}$ and $\mathrm{Cu}$ is crucial to the functioning of the young pig. Nevertheless, there is a lack in the understanding of the role of these trace elements, especially in the young pig. 
How then should we feed the young pig so that we fulfil its need for $\mathrm{Zn}$ and $\mathrm{Cu}$ and at the same time pay regard to the environmental aspects? Bearing this in mind, several points have to be addressed:

- the basic function of $\mathrm{Cu}$ in young pigs

- the basic function of $\mathrm{Zn}$ in young pigs

- the interactions between $\mathrm{Zn}$ and $\mathrm{Cu}$ and their functional consequences

- the availability of the dietary intrinsic $\mathrm{Zn}$ and $\mathrm{Cu}$ content and of the $\mathrm{Zn}$ and $\mathrm{Cu}$ sources used for dietary supplementation

- the specific physiologic need of $\mathrm{Zn}$ and $\mathrm{Cu}$ in terms of available amounts.

Finally, it might be important and necessary in the future to relate the young piglet's need for $\mathrm{Cu}$ and especially $\mathrm{Zn}$ to daily amounts per pig instead of per $\mathrm{kg}$ diet. This will enable us to focus more directly on the specific process of weaning and the possibilities to reduce the post weaning problems, i.e. diarrhoea and failure to thrive, by dietary means. Obviously, there is a great need for further research in this specific field.

\section{REFERENCES}

Apgar J., 1985. Zinc and reproduction. Ann. Rev. Nutr. 5, 43-68

Brink M.F., Becker, D.E., Terrill, S.W., Jensen A.H., 1959. Zinc toxicity in the weanling pig. J. Anim. Sci. 18, 836-842

Butler E.J., Curtin M.J., 1973. The effects of Escherichia coli endotoxin and ACTH on the plasma zinc concentration in the fowl. Res. Vet. Sci. 15, 363-367

Chesters J.K., Will M., 1981. Measurement of zinc flux through plasma in normal and endotoxinstressed pigs and the effects of zinc supplementation during stress. Brit. J. Nutr. 46, 119-130

Cousins R.J., 1985. Absorption, transport, and hepatic metabolism of copper and zinc: Special reference to metallothionein and ceruloplasmin. Physiol. Rev. 65, 238-309

Davis G.K., Mertz W., 1987. Copper. In: W. Mertz (Editor). Trace elements in human and animal nutrition. 5th Edition. Vol. 1, pp. 301-364

Golden B.E., Golden M.H.N., 1985. Zinc, sodium and potassium losses in the diarrhoeas of malnutrition and zinc deficiency. Trace Elements in Man and Animals TEMA 5. In: C.F. Mills, I. Bremner, J.K. Chesters (Editors). Proceedings of the 5th International Symposium on Trace Elements in Man and Animals, pp. 228-232

Hahn J.D., Baker D.H., 1993. Growth and plasma zinc responses of young pigs fed pharmacologic levels of zinc oxide. J. Anim. Sci. 71, 3020-3024

Jensen M.S., Gabert V.M., Larsen T., 1998. Pancreatic secretion of zinc and carboxypeptidase A and $B$ in growing pigs. Reprod. Nutr. Dévelop. (submitted)

Keen C.L., Hurley L.S., 1987. Effects of zinc deficiency on prenatal and postnatal development. Neuro Toxicol. 8, 379-388

Keen C.L., Gershwin M.E., 1990. Zinc deficiency and immune function. Ann. Rev. Nutr. 10, 415-431

Kirchgessner M., Beyer M.G., Steinhart H., 1976. Activation of pepsin (EC 3.4.4.1) by heavy-metal ions including contribution to the mode of action of copper sulphate in pig nutrition. Brit. $\mathbf{J}$. Nutr. 36, 15-23 
Larsen M.M., Bak J., Scott-Fordsman J., 1996. Monitering af tungmetaller i danske dyrkningsog naturjorder. Prøvetagningen 1992/93. Faglig rapport Nr.157, Danmarks Miljøunders gelser

Larvor P., 1983. The pools of cellular nutrients: Minerals. In: P.M. Riis (Editor). Dynamic biochemistry of animal production. World Anim. Sci. A3, 281-317

Magid J., 1997. [Heavy metals and soil quality]. Tidsskrift for Landøkonomi 2, 77-80

McClain C.J., Adams L., Shedlofsky S., 1988. Zinc and the gastrointestinal system. In: A. Prasad (Editor). Essential and toxic trace elements in human health and disease. Alan R. Liss, Inc., New York, pp. 55-73

Poulsen H.D., 1989. Zinc oxide for weaned pigs. Procecdings of the 40th Annual Meeting of the European Association for Animal Production, Dublin, Ireland, Vol. 2, pp. 265-266

Poulsen H.D., 1995. Zinc oxide for weanling piglets. Acta Agric. Scand., Sect. A. Anim. Sci. 45, 159-167

Poulsen H.D., Larsen T., 1995. Zinc excretion and retention in growing pigs fed increasing levels of zinc oxide. Livest. Prod. Sci. 43, 235-242

Prasad A.S., 1985. Clinical manifestations of zinc deficiency. Ann. Rev. Nutr. 5, 341-363

Prohaska J.R., 1988. Biochemical functions of copper in animals. In: A.S. Prasad (Editor). Essential and toxic trace elements in human and health and disease. Alan R. Liss, Inc., New York, pp. 105-124

Radecki S.V., Ku P.K., Bennink M.R., 1992. Effects of dietary copper on intestinal mucosa enzyme activity, morphology and turnover rates in weanling pigs. J. Anim. Sci. 70, 1424-1431

Shurson G.C., Ku P.K., Waxler G.L., Yokoyama M.T., Miller E.R., 1990. Physiological relationships between microbiological status and dietary copper levels in the pig. J. Anim. Sci. 68, 1061-1071

Sternlieb 1., 1988. Copper and zinc. In: 1.M. Arias, W.B. Jakoby, H.Popper, D. Schachter, D.A. Shafritz (Editors). The liver: biology and pathobiology. Raven Press, Ltd., New York, pp. $525-533$

Wedekind K.J., Baker D.H., 1990. Zinc bioavailability in feed-grade sources of zinc. J. Anim. Sci. 68, 684-689

Wedekind K.J., Hortin A.E., Baker D.H., 1992. Methodology for assessing zinc bioavailability: Efficacy estimates for zinc-methionine, zinc sulphate, and zinc oxide. J. Anim. Sci. 70, 178-187

Whitenack D.L., Whitehair C.K., Miller E.R., 1978. Influence of enteric infection on zinc utilization and clinical signs and lesions of zinc deficiency in young swine. Amer. J. Vet. Res. 39, 1447-1454

Zhou W., Kornegay E.T., Laar van H., Swinkels J.W.G.M., Wong E.A., Lindeman M.D., 1994a. The role of feed consumption and feed efficiency in copper-stimulated growth. J. Anim. Sci. 72, 2385-2394

Zhou W., Kornegay E.T., Lindeman M.D., Swinkels J.W.G.M., Welten M.K., Wong E.A., 1994b. Stimulation of growth by intravenous injection of copper in weanling pigs. J. Anim. Sci. 72 , 2395-2403 